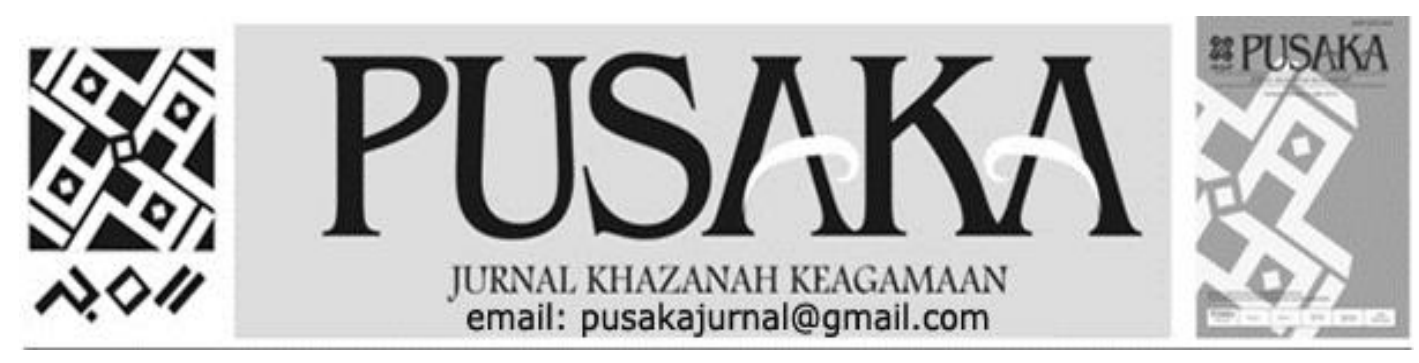

\title{
Jaringan Ulama Awal Abad XX Kabupaten Sidrap dan Parepare
}

\author{
Ulama Network of Twenthy Century Sidrap and Parepare District
}

\author{
Wardiah Hamid \\ Balai Penelitian dan Pengembangan Agama Makassar \\ Jl.A.P.Pettarani No.72 Makassar. Telp:0411-452952 \\ Email: wardiahlitbang@yahoo co.id.
}

\begin{tabular}{|c|c|}
\hline $\begin{array}{c}\text { Info } \\
\text { Artikel }\end{array}$ & Abstract \\
\hline $\begin{array}{c}\text { Diterima } \\
2 \\
\text { Agustus } \\
2018 \\
\text { Revisi I } \\
5 \\
\text { Oktober } \\
2018\end{array}$ & $\begin{array}{l}\text { Penelitian ini bertujuan untuk menggambarkan fakta sejarah jaringan ulama awal } \\
\text { abad XX di dua daerah yaitu Sidrap dan Parepare terbangun secara intens. Dengan } \\
\text { menggunakan jenis penelitian kualitatif deskriptif dan metode pengumpulan data } \\
\text { yaitu observasi, wawancara dan dokumentasi. Hasil penelitian menunjukan bahwa } \\
\text { jaringan ini terbentuk melalui transmisi intelektual dalam bentuk pengajian } \\
\text { tradisonal yang biasa disebut mangngaji tudang. Untuk memperkuat jaringan ini } \\
\text { dijalin dengan mengadakan tali perkawinan diantara sesama keluarga ulama lain. } \\
\text { Suatu dampak yang brilian tertuang melalui Ide maupun gagasan lahir dengan } \\
\text { terbentuknya halaqah-halagah, Sekolah Arab hingga pendirian pondok pesantren } \\
\text { diberbagai wilayah Sidrap maupun Parepare. Tersebutlah para ulama di dua tempat } \\
\text { ini antara lain KH. Bahsen Salman, KH. Mahmud Fasieh, KH. Muhammad Sanusi } \\
\text { Maggu, Hakim Lukman dan Syekh Jamal Usman Padaelo. } \\
\text { Kata kunci: Jaringan, Ulama, Sidrap, Parepare. }\end{array}$ \\
\hline $\begin{array}{c}\text { Revisi II } \\
15 \\
\text { Oktober } \\
2018 \\
\\
\text { Disetujui } \\
1 \\
\text { November } \\
2018\end{array}$ & $\begin{array}{l}\text { This study has the purpose of describing the historical facts of early twentieth- } \\
\text { century ulama networks in two regions namely Sidrap and Pareparetarbangun } \\
\text { intensely. By using descriptive qualitative research types and data collection } \\
\text { methods namely observation, interviews and documentation. The results showed } \\
\text { that this network was form edthrough intellectual transmission in the form of } \\
\text { traditional recitation which is commonly called the mangrovesign. To streng then } \\
\text { this network, it was established by holding a marriage ropeamong fellow } \\
\text { clericalfamilies. A brillian timpactis expressed through the Idea sandideas born } \\
\text { with theformation of halaqah-halaqah, Sekolah Arab until the establishmentof } \\
\text { Islamic boardingschools in various Sidrap and Parepareareas. The mention } \\
\text { edscholars in these two places include KH. Bahsen Salman, KH. Mahmud Fasieh, } \\
\text { KH. Muhammad Sanusi Maggu, Hakim Lukman and Sheikh. Jamal Usman } \\
\text { Padaelo. } \\
\text { Keywords: Network, ulama, Sidrap, Parepare. }\end{array}$ \\
\hline
\end{tabular}




\section{PENDAHULUAN}

Ada banyak hal yang menghubungkan kematangan seseorang dalam menjaring standar keilmuan yang dalam. Salah satunya adalah mengadakan rihlah ke tempat jauh untuk mendalami keilmuan yang lebih luas lagi. Rihlah yang dilakukan oleh para ulama terdahulu tentu saja bukan sesuatu yang mudah. Alat transportasi yang sangat terbatas bukan menjadi penghalang mereka untuk menimba ilmu ke negeri lain, jauh meninggalkan pulau Celebes menuju pusat jantung Islam Mekah maupun Medinah. Dua negeri ini adalah pusat atmosfer untuk memahami Islam lebih jauh. Di tempat ini diawal abad XX menjadi magnet tersendiri bagi para perantau dari tanah Bugis untuk dijadikan target dan tempat tujuan dalam menimba ilmu agama.

Berhaji ke tanah suci adalah dambaan setiap muslim Nusantara, di tahun 1920 sudah mempergunakan kapal uap menurut Ordonansi Haji tahun 1922 "Peraturan Tentang Pelayaran Haji" Dalam Ordonansi tersebut dijelaskan tentang jenis kapal yang dipakai untuk mengangkut jamaah Haji. Maskapai pelayaran diwajibkan untuk menggunakan kapal uap sebagai sarana pengangkutan dengan persyaratan yang harus dipenuhi. Ada beberapa tempat yang menjadi pelabuhan Embarkasi yaitu Makassar, Surabaya, Tanjung Periuk, Emmahaven, Palembang, dan Sabang (Abdurrahman, 2016: 38).

$\begin{array}{ccc}\text { Ketika } & \text { kapal uap mulai } \\ \text { beroperasi } & \text { di } & \text { Nusantara }\end{array}$ menyeberangi perairan di pulau Celebes, maka beberapa ulama lokal dari tanah Bugis berlomba-lomba menumpangi kapal-kapal itu untuk dijadikan transportasi yang mengantarkan mereka ke daratan Timur Tengah. Mereka mukim untuk beberapa lamanya di Mekah maupun Madinah untuk mencapai cita-cita yang mereka bawa dari tanah air yaitu belajar agama di samping tujuan utama mereka adalah menunaikan ibadah haji.

Setelah beberapa lamanya mendalami ilmu agama, maka mereka akan kembali ke Nusantara dengan membawa ide maupun gagasan untuk di kembangkan di tanah air mereka masing-masing. Dampak jauh yang mereka timbulkan terjadinya sebuah jaringan yang saling terhubung dari segi tempat yaitu Mekah dan Medinah sebagai transmisi keilmuan Haramain. Beberapa ulama Haramain menjadi tempat mereka menuntut ilmu sehingga menimbulkan keterkaitan jaringan yang tersimpul dalam hubungan guru dan murid.

Para ahli Islam, mengungkap bahwa hubungan para orang-orang Timur Tengah dan Asia Tenggara telah memberikan wawasan baru yang terpenting mengenai kontak para ulama, yang ikut serta dalam jejaring yang melintasi Samudera Hindia. Kegiatan-kegiatan itu menimbulkan pertukaran ilmu Islam (Kersten, 2017: 104). Perkembangan cukup urgen ialah di pertengahan abad 19, anakanak muda dari seluruh pelosok Nusantara mendatangi kota Mekah dan tinggal menetap untuk beberapa tahun untuk memperdalam pengetahuan mereka. Bahkan sebahagian besar di antara mereka menjadi ulama terkenal dan mengajar di dua kota suci ini. Para ulama ini turut aktif dalam transmisi keilmuan. (Dhofier, 2011: 68). 
Dengan demikian di antara seluruh jamaah haji, orang Nusantara merupakan pendatang terbanyak mendatangi dua kota Suci ini. Pada akhir abad ke-19 dan awal abad ke 20, jumlah mereka berkisar antara 10 dan 20 persen dari seluruh jemaah haji asing, walaupun mereka datang dari negeri jauh dari pada yang lain. Malah pada dasawarsa 1920-an sekitar 40 dari seluruh jemaah haji berasal dari Nusantara (Bruinessen, 2015: 3). Jaringan atau hubungan antar orang Arab dalam hal daratan Timur Tengah mempunyai ikatan yang kuat yang memotivasi lebih besar untuk saling membantu dalam segala hal termasuk transmisi keilmuan (Hamid, 260: 2017).

Beberapa potensi positif yang dibawa oleh para penuntut ilmu ini adalah terbentuknya sebuah transmisi keilmuan di tanah Bugis kemudian dimanifestasikan dalam bentuk halaqah, Sekolah Arab, Pesantren, maupun manuskrip-manuskrip yang masih disimpan oleh masyarakat di mana para ulama itu hidup dan mengembangkan jaringan keilmuannya.

Jaringan atau hubungan antar ulama yang satu dengan yang lainnya tersimpul dalam ikatan murid dan guru. Jaringan ini mempunyai ikatan kuat yang memotivasi lebih besar untuk saling membantu dan lebih cepat untuk saling memberikan bantuan, ide maupun gagasan.

Dari latar belakang di atas maka permasalahan penelitian ini adalah bagaimana jaringan transmisi keilmuan berlangsung dan terbentuk di kota Parepare dan Kabupaten Sidrap. Siapa saja tokoh tokoh ulama di kota Parepare dan kabupaten Sidrap dengan kiprah yang mereka torehkan sebagai dampak dari jaringan tersebut. Berdasarkan dari permasalahan di atas, maka penelitian ini bertujuan untuk melakukan penggalian data hingga terbentuk rekonstruksi jaringan ulama Sidrap dan Parepare pada awal abad XX. Adapun manfaat yang bisa diambil dari penelitian ini. hasil dari penelitian ini menjadi data-data keagamaan yang bisa dijadikan bahan pertimbangan dalam penentuan kebijakan. Semua pihak intelektual yang berkecimpung dibidang keilmuan menjadikannya sebagai ilmu sejarah awal tentang keberadaan para ulama di Kota Parepare dan kabupaten Sidrap.

Teori lain yang mendukung penelitian tentang Jaringan Ulama adalah teori jaringan yaitu pemusatan perhatiannya pada struktur sosial mikro dan makro. Artinya bagi teori jaringan, aktor mungkin saja individu tetapi mungkin juga kelompok. Hubungan bisa terjadi ditingkat struktur sosial skala luas maupun yang lebih kecil. Hubungan ini berlandaskan gagasan bahwa setiap aktor (individu atau kolektivitas) mempunyai akses berbeda terhadap sumber daya yang bernilai (kekayaan, kekuasan, informasi) (Goodman, 2007: 383). Dalam penelitian ini yang dimaksud dengan jaringan ada hubungan yang terjalin oleh beberapa aktor yang mentransmisikan ilmunya apakah melalui ide dan gagasan.

Kata 'ulama secara terminologi bermakna orang-orang yang diakui sebagai cendekiawan atau sebagai pemegang otoritas pengetahuan agama Islam. Bisa saja mereka adalah para imam masjid-masjid besar (agung), para hakim (agama Islam), dosen-dosen agama pada universitas 
(perguruan tinggi Islam), dan yang secara umum ia merupakan lembaga kelompok terpelajar atau kalangan cendekiawan keislaman yang memiliki hak penentu atas permasalahan keagamaan Islam (Glasse, 2002: 417).

Dalam jaringan ulama ini telah tercipta hubungan yang intens antara guru dan murid di kalangan para ulama tersebut umumnya di dunia muslim. Ketika interaksi tersebut terjalin ada beberapa faktor yang melatar belakangi hubungan tersebut apakah berbentuk perdagangan yang biasa juga disebut bidang ekonomi, politik kemudian menjadi legitimasi mereka untuk saling berinteraksi di antara mereka. (Azra, 2013:1:123). Legitimasi itu bisa terlihat apakah para ulama ini di panggil Kiai, annangguru, dan gurutta.

Dalam penelitian ini menggunakan metode penelitian deskriptif kualitatif, menggambarkan secara mendalam jaringan ulama yang saling terkait antara satu dengan yang lainnya. Adapun teknik yang digunakan dalam penelitian ini yaitu wawancara mendalam dengan informan, studi dokumen dan observasi lapangan. Data yang terkumpul dianalisis dalam tahapan penulisan dan dianalisis ketika direduksi, kemudian disajikan dalam bentuk deskripsi. Dalam analisis data kualitatif dilakukan secara interaktif dan berlangsung terus menerus sampai tuntas, sampai data menjadi jenuh (Milles and Huberman, 1984).

\section{PEMBAHASAN}

\section{Ulama Sidrap dan Parepare}

Mereka hidup pada zamannya dan memainkan peranan di zamnnya pula. Melacak keberadaan para ulama ini, perlu perhatian lebih dan fokus. Jaringan ulama yang saling terkait antara satu dengan lainnya terbentuk dalam jaringan intelektual yang mereka bangun sepanjang awal abad XX. Jaringan keilmuan mereka menjadi sebuah tradisi, di mana pesantren, karya tulis mereka tinggalkan sebagai warisan peninggalan buat generasi selanjutnya.

Beberapa ulama di Parepare telah terinventarisir pada umumnya pernah membantu dan ada pernah belajar pada Gurutta KH. Ambo Dalle. Seperti: KH. Zainuddin Daeng, Mabung, KH. Zainuddin Badu, BA, KH. M. Yusuf Hamzah, KH. Harun Al-Rasyid, KH. Abd. Hakim Lukman (Ketua Pengadilan Agama Kota Parepare, periode 1959-1967), KH. Bahsen Salman, KH. Aqib Siangka (Ketua Pengadilan Agama Kota Parepare, periode 1967-19800, KH. Abd. Rahman Firdaus, K. Muhammad As'ad Al-Yafie, KH. Muhammad Nuhwaqif, KH. Mahmud Pasih, KH. Abubakar Zaenal, KH. Muhammad Iskandar S, Drs. KH. M. Arief Fasieh, KH. Iskandar Ali, Prof DR.H. Muiz Kabry, MA, DR. KH. Abd. Halim Kuning, LC, MA, Prof. Dr. KH. Abd Rahim Arsyad, MA.

Sedangkan di Kabupaten Sidrap antara lain : KH. Syekh Jamal Usman Padaelo, KH. Muin Yusuf, KH. Syekh Ali Mathar, KH. Abd. Salam, KH. Abd. Razak, KH. Hakim Lukman, KH. Abdurrahman, BA, KH. Makka Abdullah, KH. Muhammad Nuh, KH. Muhammad Thoaib, dan KH. Mangka.

Kiprah ulama dalam pengembangan Islam seperti $\mathrm{KH}$. Bahsen Salman (1921-2003). Sosok Bahsen Salman menjadi salah satu 
perintis berdirinya Madrasah Diniyah sekaligus menjadi pengajar di tempat itu. Madrasah Diniyah ini biasa juga disebut Sekolah Arab yang sekarang bermetamorfosis menjadi Yayasan Pondok Pesantren Al-Salman Allakuang Sidrap. Pondok Pesantren As Salman Allakuang ini menjadi salah satu pondok pesantren yang terkenal di Kota Sidrap dan tetap eksis sebagai media pendidikan pesantren. Yang bertindak sebagai ketua Yayasan adalah DR. H. Kaswad Sartono, M.Ag. Adapun lahan tempat berdirinya Pondok pesantren ini adalah tanah seluas 2 hektar adalah wakaf dari keluarga As Salman diantaranya adalah KH. Bahsen Salman, H. Muhammad Siata Salman, Hj. Maemunah Salman, Hj. Naimah Salman, Hj. Harisah Salman, dan $\mathrm{Hj}$ Thahirah Salman.

\section{KH. Bahsen Salman}

Bahsen Salman diperkirakan lahir pada tahun 1921 di Allakuang, jaringan keilmuannya awalnya di sekolah Rakyat (SR) 1928, kemudian melanjutkan ke Madrasah Makarimal Akhlak Allakkuang Sidrap. Keinginanya untuk memperdalam ilmu agama sehingga berinisiatif untuk meninggalkan kampung halamannya menuju Sengkang. Madrasah Arabiyah Islamiyah adalah pijakannya untuk memperdalam ilmu agama lebih luas lagi. Jaringan keilmuanya berguru KH. Muhammad As'ad menjadi gurunya di MAI Sengkang. Adapun teman belajarnya di MAI adalah KH. Muhammad Abduh Pabbajah yang kemudian menawarinya menjadi Imam Masjid Raya Parepare. Beliau menjalani pengabdian sebagai pengajar Sekolah Arab di Allakuang, dan menjadi imam juga di Masjid Raya Parepare. Dengan jarak sekitar $30 \mathrm{~km}$ antara Parepare dan Allakuang Sidrap dijalaninya bertahun tahun sebagai bentuk pengabdiannya dengan ikhlas. Kecintaanya terhadap ilmu pengetahuan dijabarkannya dengan membuka toko buku bernama Toko B.Salman Parepare yang lokasinya tidak jauh dari Masjid Raya. KH. Bashen Salman kemudian memutuskan untuk menjadi imam tetap di Masjid Raya Parepare pada tahun 1971. Dengan pertimbangan bahwa toko bukunya yang sudah mulai berkembang, beliau kemudian meninggalkan Kota Sidrap untuk menetap di Kota Parepare. Hingga akhir hayatnya meninggal tahun 2003 dalam usia 82 tahun dan di kebumikan di kampung halamannya Allakuang. Beliau termasuk imam yang paling lama, setelah meninggal beliu diganti oleh $\mathrm{KH}$. Zaenuddin Badu, BA (kemanakan Gurutta Abduh Pabbaja). (Wawancara, Muh. Jawwad, cucu KH. Bahsen Salman, 26-7-2018 di Parepare). Beliau adalah ulama yang tidak pernah bersentuhan dengan wilayah pemerintahan, ini terbukti ketika ditawari menjadi anggota dewan, dan menjadi pegawai di bawah Departemen Agama Enrekang, tetapi menolak dengan alasan bahwa menjadi imam lebih baik baginya.

\section{KH. Mahmud Fasieh}

Jaringan intelektual KH. Mahmud Fasieh (1908-1971) terhubung langsung dengan Haramyn, gurunya di Mekah antara lain seperti : Syekh Muhammad Alwi Maliki, Syekh Muhammad al-Magraby, Syekh Muhammad Amin Kutuby, Syekh Abbas Abdul Jabbar, Syekh 
Muhammad

al-Massyath.

Kepergiannya ke tanah suci setelah beliau mempunyai kematangan keilmuan di tanah Bugis. Ketika kembali dari tanah suci terlebih dahulu singgah di Pulau Sumatera, beliau mendirikan Cabang DDI di Riau dan Jambi, dan menjadi pendiri/penggagas Madrasah Arabiayah Islamiyah Bugisiyah, Tampok Benno Johar Malaya (beliau waktu itu bolak balik MekahMalaya).

Pertama

mengenyam

pendidikan awal di Sekolah Rakyat SR di Belawa tahun 1920. Kemudian melanjutkan pendidikan ke Madrasah Arabiyah Islamiyah (MAI) Sengkang, pimpinan KH. Muhammad As'ad, tahun 1935. Beliaupun pernah berguru kepada KH. Aburahrahman Ambo Dalle, tahun 1940-1947 di Madrasah Arabiyah Islamiyah (MAI/DDI Mangkoso). Pada tahun 1971, beliau kembali ke pulau Sulawesi tepatnya di Parepare membantu Guruta Ambo Dalle di DDI Ujung Lare. Beliau meninggalkan beberapa karya tertulis diantaranya Madaarijil Lugatul Arabiyah, Mir'atul Musafirina Ilal Jannati Bissaadatil Abadiyyati, Syahinul Mauidhati (Mantegana PangajaE), Maj'muatil Nasyidatil Mudarrisati (Arab, Bugis, Indonesia) Drs. KH. Arif (Wawancara Fasieh, mantan Kakandep. Agama Kota Parepare: 24-7-2018).

Bukan hanya karya tertulis yang beliau tinggalkan tetapi juga pernah mengembang amanah antara lain Kordinator Daerah Darud Dakwah Wal Irsyad (DDI) Riau dan Jambi, Pengurus Jam'iyahNahdhatul Ulama, INHIL, Anggota/KH. Alifah Thariqat Naqsyabandiyah (PTII), Jakarta.
KH. Muhammad Sanusi Maggu

Terlahir dari pasangan suami istri La Maggu dan I Canname, dilahirkan di Desa Lise Kecamatan Pancalautan Kabupaten Sidenreng Rappang, kedua orang tuanya memberi nama Sanusi. Salah satu gurunya $\mathrm{KH}$. Ibrahim adalah perintis lahirnya Madrasah Muhammadiyah di Rappang, dibantu guru-guru dari Sumatra seperti Abdul Jalil dan Abdul Rauf. Semenjak belajar kepada KH. Ibrahim tentang pelajaran Islam, sudah terlihat kemampuan Sanusi kecil memahami agama secara baik dan tekun, sehingga gurunya kemudian menambah namanya Muhammad Sanusi Maggu. Sanusi waktu kecilnya belajar mengaji Al Qur'an, mulai dari alepu hingga massara' baca di rumah Haji guru (imam Desa Lise). Setelah tamat, dia pindah ke Rappang Kecamatan Panca Rijang mengaji pondok di bawah bimbingan $\mathrm{KH}$. Ibrahim, ayah dari KH. Malik Ibrahim selama 12 tahun. Bacaan Alquran Sanusi Maggu sering dipuji oleh gurunya karena kecepatannya memahami pelajaran yang diberikan kepadanya dan kebagusan bacaannya.

Setelah menyelesaikan proses pendidikan, Muhammad Sanusi Maggu kembali ke Lise. Di Lise, dia mulai tampil mendakwakan ilmunya yang telah diperoleh selama mengikuti pendidikan di Rappang. Tetapi tidak berapa lama di Lise, Muhammad Sanusi Maggu hijrah ke Parepare dan bergabung dalam organisasi Muhammadiyah cabang Parepare (Bosra, 2015: 171).

Ketika Muhammad Sanusi Maggu menetap di Parepare, kemudian $\mathrm{H}$ Abdul Malik Karim Amrullah (HAMKA) datang ke 
Makassar, mendengar bahwa di Makassar ada seorang ulama dari Minangkabau, Muhammad Sanusi Maggu pun hijrah ke Makassar dengan maksud berguru kepada Hamka. Maksud dan keinginannya pun tercapai, setelah Muhammad Sanusi Maggu diterima belajar di Madrasah Muallimin yang waktu itu lebih dikenal dengan nama Tabligh School yang dipimpin Hamka.

Jabatan-jabatan

dalam

Muhammadiyah dan amal usaha yang pernah diembang oleh KH. Muhammad Sanusi Maggu, adalah Kepala SMP Muhammadiyah Sengkang, Kepala SMA Muhammadiyah Parepare, Ketua Pimpinan Wilayah Muhammadiyah Sulawesi Selatan 1980-1984. Aktivitas dan jabatan yang pernah diembannya di luar Muhammadiyah antara lain, adalah sebagai pejuang perintis kemerdekaan bersama Andi Abdullah Bau Massepe, Andi Makkasau, dan La Nakka. Dia juga pernah menjadi Anggota DPRD Parepare mewakili Muhammadiyah selama beberapa bulan karena dia mengundurkan diri sebelum masa tugasnya berakhir. Alasan pengunduran dirinya adalah karena dia merasakan bahwa dunia politik bukanlah dunianya. Dia juga pernah menjadi ketua Majelis Ulama Kota Parepare. (Wawancara Prof. Muh Siri Dangnga: 3 Juli 2018)

KH. Muhammad Sanusi Maggu meninggal pada hari Sabtu tanggal 24 Februari 1990, tepatnya pada tanggal 28 Rajab 1410 Hijriah di Parepare. Jabatan beliau pada masa hidupnya: Pimpinan Muhammadiyah Parepare, Wakil Ketua Pimpinan Muhammadiyah Wilayah Sulawesi Selatan Tenggara. Beliau pernah jadi anggota DPRD Parepare sekitar tahun 1970-an menggantikan Andi Bahtiar karena Andi Bahtiar PNS. Pada waktu Musyawarah Muhammadiyah di Bulukumba beliau terpilih sebagai Pimpinan Muhammadiyah wilayah pada tahun 1979 (Bosra, 2015 :171).

Dukungan terhadap pemerintah bisa dilihat bahwa pernah suatu waktu dia mengkritik Pak Walikota Andi Mallarangeng masalah tentang LOTTO di Parepare, beliau memohon supaya LOTTO diberhentikan, Pak Walikota mengatakan: "biarkan berjalan saja, kalau ada dosanya nanti saya yang tanggung." Pak Kiai marah. Dia memukul meja, tidak ada istilah menanggung dosa seseorang dengan menyampaikan alasan-alasan argumentasi. Pada waktu itu pemasukan dari LOTTO pemerintah banyak dia pergunakan untuk perbaikan sarana jalan.

Di UMPAR (Universitas Muhammadiyah Parepare) namanya di abadikan sebagai nama masjid (Masjid KH. Muhammad Sanusi Maggu). Masjid tersebut dipakai mahasiswa sebagai tempat pembimbingan dan di wilayah lokasi masjid tersebut dilengkapi tempat penginapan bagi mahasiswa bimbingan (rumah susun) seperti di Pesantren UMI di Padanglampe. Namanya diabadikan sebagai nama jalan seperti di kecamatan Soreang, ada satu jalan menuju ke Masjid Tarbiyah Lontange, terpasang sebagai nama Jalan KH. Sanusi Maggu.

Pada tahun 1965, pada masa Westerling di Rappang, beliau sudah dijejer di lapangan mau ditembak, pada waktu tuan raja menarik pak Sanusi Maggu keluar dari barisan ahirnya dia tidak jadi di tembak. Beliau pernah menyampaikan kepada 
warga Muhammadiyah bahwa organisasi bisa maju kalau ekonominya maju, maka harus diperkuat ekonomi. (Wawancara $\mathrm{Hj}$. Ramlah Sanusi: 1 Agustus 2018).

\section{KH. Hakim Lukman}

Hakim Lukman lahir pada tahun 1917, di sebuah kampung yang bernama Amparita. Desa Amparita Kecamatan Maritengngae Sidrap. Bapaknya bernama Haji. Lukman (guru Kemman). Riwayat pendidikannya yaitu Sekolah Rakyat tamat pada tahun 1928. Selama itu hanya pendidikan nonformal. Gurunya diantaranya $\mathrm{KH}$. Muhammad Yafie, dan KH. Abdurrahman Ambo Dalle. Beberapa ulama yang sezaman dengannya adalah KH. Ali Yafie dan KH. Harun Arrasyid.

Jabatan yang pernah diemban antara lain: KUA Distrik Massepe, Rohaniawan Korem Parepare, Ketua Pengadilan Agama Mahkamah Syariah Kabupaten Parepare yang meliputi Ajattappareng (Barru, ParePare, Pinrang Sidrap dan Enrekang) 1959-1967. Setelah Pengadilan Agama Sidrap terbentuk pada tahun 1967, beliau ditunjuk sebagai ketua sampai tahun 1976 kemudian diganti oleh KH. Makka. Beliau pernah jadi Anggota Dewan Perwakilan Rakyat Daerah pada tahun 1977-1987.

KH. Hakim Lukman, pernah diculik masuk hutan bersama $\mathrm{KH}$. Abdurrahman Ambo Dalle, tapi beliau tidak lama karena ada tentara yang melihat dan kenal baik dengan beliau ahirnya disuruh masuk ke Kota untuk mengajar (Parepare). Kaderkadernya seperti KH. Abdurrahman, BA. KH. Abd. Razak (Imam Soreang), KH. Muhammad Thoaib,
KH. Muhammad Nuh, KH. Abubakar Madjid, KH. Mangka (Mantan Kepala Kantor Departemen Agama Sidrap), Drs. H M. Alwy Radjab, Drs. H. Halim Yahya (Mantan Ka. PGA. Parepare.) H. Muhsin (Imam Masjid Lakessi) Hanafi Taman (Imam Masjid Hamkam Parepare), KH. Hakim Lukman. Jaringan kekeluargaannya terhubung dengan KH. Muhammad Abduh Pabbaja (sepupu). Untuk mempererat jaringan kekerabatan dengan KH. Harun Ar-Rasyid, ia mengawini adik dari istri Harun ArRasyid.

Tidak hanya bergelut di bidang dakwah agama, beliau menjadi penggiat ekonomi bagi masyarakat sekitarnya. Dengan mendirikan pabrik penggilingan beras, dan setiap selesai berdakwah di daerah Soppeng senantiasa membeli tembakau untuk dibawanya ke Amparita. KH. Hakim Lukman menghembuskan napas terakhirnya pada tahun 2002 dan dikebumikan di Pekuburan Islam Amparita (Wawancara, Mahmud Hakim: 29 Juli 2018).

\section{Syekh Jamal Usman Padaelo}

Syekh Jamal Usman Padaelo dilahirkan di Hijaz Kota suci Mekah pada tahun 1876 dari pasangan $\mathrm{H}$. Usman dan $\mathrm{Hj}$. Aisyah. Keduanya merupakan keturunan Bugis yang sudah menetap di tanah haram. Dari garis keturunan ibu, Syekh Jamal Usman Padaelo memiliki pertalian darah dengan Syekh Yusuf ArRaffany. Kata Padaelo yang mengikuti nama beliau bukanlah merupakan garis nasab. Tetapi merupakan nama salah satu kampung di daerah Belawa tempat beliau bermukim pertama kalinya saat tiba di tanah Bugis sebelum akhirnya pindah 
ke Rappang (Wawancara $\mathrm{Hj}$. Soraya Fandi Khalik, Putri Hj. Aisyah Binti Syekh Jamal Usman Padaelo, Rappang (Wawancara, 7 Agustus 2018).

Jika menyimak tahun kelahiran Syekh Jamal, kemudian dibandingkan dengan ulama-ulama di Sulawesi Selatan, usia Syekh Jamal Usman Padaelo tergolong paling senior. Beliau hampir seusia dengan $\mathrm{KH}$. Hasyim Asy'ari yang lahir pada tahun 1875. Usia beliau terpaut begitu jauh dengan Anregurutta KH. Ramli dan KH. Ahmad Bone yang merupakan pendiri Rabithah Ulama yang menjadi embrio lahirnya NU di Sulawesi Selatan.

Tempat kelahiran beliau berada di sekitar Bukit Shafa dan Marwah. Menurut informasi dari beberapa pihak keluarga, kawasan tempat Sa'i yang megah saat ini masih merupakan tanah milik Syekh Jamal yang diwarisi dari orang tuanya. Masa kecil Syekh Jamal dihabiskan di sekitar Mesjidil Haram sambil menuntut ilmu di al Madrasatul Ilmi Darul Falaah Mekah, hingga akhirnya beliau menjadi seorang ulama (Wawancara, H. Surkati Muin, Ketua Dewan Pembina Yayasan P.P. Al Urwatul Wutsqaa, Benteng, Sidrap, Putra AGH. Abd. Muin Yusuf dengan Hj. Badariah Binti Syekh Jamal Usman Padaelo, di Rappang, 6 Agustus 2018).

Saat terjadinya pergantian kekuasaan tersebut di Tanah Mekah, Syekh Jamal Usman Padaelo, yang berpaham yang Ahlussunnah Wal Jamaah dengan bermadzhab Syafi'I, meninggalkan kampung halamannya untuk berhijrah dan membawa semua keluarganya untuk menetap di Tanah Bugis tepatnya di Rappang. Alasan utama hijrah beliau karena tidak sepaham dengan pemerintah Kerajaan Saudi yang bermadzhab Hambali. Di tempat inilah Syekh Jamal Usman memusatkan aktifitasnya dalam menyebarkan agama Islam di Sidenreng Rappang dan sekitarnya.

Syekh Jamal Usman Padaelo menikah dengan seorang gadis di Rappang yang bernama $\mathrm{Hj}$. Jamilah. Dari hasil pernikahan ini lahir 4 orang putra dan putri yakni: $\mathrm{Hj}$. Aisyah; $\mathrm{Hj}$. Hasanah. (Hj. Kambe nama panggilan $\mathrm{Hj}$. Badariah isteri Anregurutta KH. Abd. Muin Yusuf) dan H. Ahmad Jamal (mantan Ketua Pengadilan Agama Enrekang).

Dua orang putri Syekh Jamal, (Aisyah dan Hasanah) lahir di rumah kediamannya di Kota Suci Mekah. Sementara Ahmad Jamal dan Badariah lahir di Rappang. Meskipun kedua putra dan putri tersebut (Badariah dan Ahmad Jamal) dilahirkan di Rappang, tetapi saat keduanya masih kecil, Syekh Jamal beserta istrinya masih sering bolak balik dari Rappang ke kota Suci Mekah untuk mengurus asetnya yang ada di Mekah sambil tetap melaksanakan aktifitas dakwah dan syiar Islam di Indonesia. Bahkan $\mathrm{Hj}$. Badariah sudah berada dalam kandungan ibunya saat Syekh Jamal sudah akan hijrah ke Rappang (Wawancara, Hj. Jamaliah Khalik, Putri Hj. Aisyah binti Syekh Jamal Usman Padaelo, di Rappang 7 Agustus 2018).

Menurut keterangan dari beberapa sumber, Syekh Jamal tidak memiliki aktifitas di Rappang kecuali aktifitas pengajian dan syiar Islam. Seluruh kegiatan perekonomian beliau berada di Kota Mekah dengan mengontrakkan beberapa rumah 
miliknya untuk dijadikan usaha dalam menopang dakwah beliau di tanah Bugis. Setelah istri tercinta $\mathrm{Hj}$. Jamilah wafat, Syekh Jamal kemudian menikah dengan seorang gadis yang berasal dari Tonronge Kecamatan Baranti bernama Mahani. Dari hasil pernikahan ini lahir 3 orang putri beliau yakni: H Rugayyah; $\mathrm{H}$. Baru; dan H. Rusydiah. (Wawancara, Hj. Jamaliah Khalik, Putri Hj. Aisyah Binti Syekh Jamal Usman Padaelo, Rappang, 7 Agustus 2018).

Setelah Syekh Jamal meninggalkan Kota Mekah dan hijrah ke Rappang sekitar tahun 1922, maka pada tahun 1925 beliau diangkat menjadi Qadi Rappang. Sejak saat itu, banyak ulama-ulama yang sering datang mengunjungi beliau di Rappang Khususnya para ulama yang berada di kawasan Ajattappareng. Bahkan, rumah yang beliau tempati di Rappang sering menjadi tempat pertemuan para ulama. Dampak jauh dari pertemuan para ulama ini adalah terobosan untuk melakukan Sidang Itsbat perihal penentuan masuknya Bulan suci Ramadhan dan penetapan Hari raya Idul Fitri dan Idul Adha saat itu (Wawancara, H. Surkati Muin (Ketua Dewan Pembina Yayasan P.P. Al Urwatul Wutsqaa Benteng Sidrap, Putra A.G. KH. Abd. Muin Yusuf dengan $\mathrm{Hj}$. Badariah binti Syekh Jamal Usman Padaelo, di Rappang 6 Agustus 2018).

\section{Lembaga/jabatan}

qadi membentuk salah satu kedudukan penting dalam sistim peradilam pada jaman itu, memberi mereka ruang yang seluas-luasnya dalam hal otoritas keagamaan. Melalui lembaga qadi para ulama ketika itu mengeluarkan fatwa dan hukum Islam dirumuskan. Dengan demikian qadi menjadi sentral dalam meregulasi setiap penentuan kehidupan umat Islam (Burhanuddin, 2012:37).

Selama beliau menjadi Qadi Rappang, banyak pertemuan penting yang dilakukannya dengan para ulama yang ada di Sulawesi Selatan. Salah satu diantaranya adalah Pertemuan Alim Ulama di Bone yang difasilitasi oleh A. Mappanyukki (Raja Bone) pada tanggal 9 Oktober 1931 dalam rangka Bahtsul Matsaail (membahas persoalan umat), perihal tarekat Khalwatiah yang ada di Maros. Pertemuan saat itu dipimpin langsung oleh Sayyid Abdullah Dahlan yang duduk berdampingan dengan A. Mappanyukki. Sekitar 30 alim ulama yang hadir saat itu antara lain, H. Ramli (Qadi Luwu); H. Usman (Qadi Soppeng), H. Abd. Hamid (Qadi Bone), H. As'ad (pendiri Pesantren As'adiyah Sengkang).

Jabatan sebagai Qadi di Sidenreng Rappang beliau jabat hingga tahun 1945 dan digantikan kemudian oleh menantunya sekaligus muridnya yakni KH. Abd. Muin Yusuf. Dari beliau inilah Anregurutta KH. Abd. Muin Yusuf mewarisi berbagai macam ilmu Khususnya ilmu ma'rifat. Karena salah satu karamah yang dimiliki oleh Syekh Jamal adalah terkadang beliau tidak terkena air hujan jika beliau menuju ke suatu tempat untuk melaksanakan pengajian. Hal inipun terjadi tentu atas izin Allah juga. Dengan karamah yang beliau miliki inilah membuatnya tidak pernah menjadikan alasan turunnya hujan sebagai hambatan untuk menjalankan aktifitas keumatan yang beliau jalankan. Karena, meskipun hujan turun beliau tetap berangkat dan sampai di tempat 
tujuan tanpa merasakan basah kuyup karena kehujanan atas pertolongan Allah SWT.

Disamping aktif dari jabatan sebagai qadi, Syekh Jamal Usman Padaelo juga aktif memberikan pengajian di beberapa daerah di kawasan Ajattappareng. Satu hal penting yang tidak sempat dilakukan oleh beliau adalah mendirikan sekolah formal seperti yang dilakukan oleh muridnya yakni Syekh Ali Mathar, yang mendirikan Madrasah Aunur Rafieq di sekitar Mesjid Raya Rappang pada tahun 1930. Hal ini mungkin disebabkan karena kesibukan beliau sebagai seorang Qadi Sidenreng Rappang yang banyak menyita waktunya. (Wawancara, Hj. Soraya Fandi Khalik, Putri Hj. Aisyah binti Syekh Jamal Usman Padaelo, di Rappang di 7 Agustus 2018).

Syekh Jamal bersama muridnya (Syekh Ali Mathar) adalah dua ulama mumpuni yang sangat banyak pemikiran keagamaannya mewarnai kehidupan keagamaan di Sidenreng Rappang Khususnya kota Rappang. Syekh Jamal menekuni profesinya di jalur struktur kekuasaan karena jabatannya sebagai qadi, sementara Syekh Ali Mathar lebih banyak berperan di dunia pendidikan. Kedua ulama inilah yang mewarnai pemikiran Anregurutta KH. Abd. Muin Yusuf sebelum beliau datang ke kota Sengkang dan berguru pada Anregurutta KH. As'ad sekitar tahun 1932 (Wawancara, Wahidin ArRaffany, Murid Anregurutta KH. Abd. Muin Yusuf Sekretaris Yayasan P.P. Al Urwatul Wutsqa Benteng tahun 2013 sekarang, 8 Agustus 2018).

Selain Anregurutta Syekh Ali Mathar dan KH. Abd. Muin Yusuf, ada juga beberapa ulama lain yang sempat berguru pada Syekh Jamal Usman Padaelo yakni KH. Umar Yusuf, salah satu ulama yang bersama-sama Anregurutta KH. Muin Yusuf mendirikan YMPI Rappang tahun 1947, KH. Ali Yafie dan lainlain.

Beberapa asumsi mendasar kedekatan Syekh Jamal dengan KH. As'ad menurut pengakuan dari cucunya H Soraya Fandi Khalik bahkan ketika KH. As'ad berada di Kota Mekah, mereka menjalin hubungan sesama perantau dari tanah Bugis dan hidup dalam majelis ilmu secara bersama-sama. Syekh Jamal Usman Padaelo adalah orang Bugis asli dengan keturunan dari Wajo yang lahir dan menetap di Mekah.

Selain aktifitas yang dijelaskan di atas, Syekh Jamal juga ternyata turut andil dalam upaya merebut kemerdekaan. Hal itu dilakukannya dengan masuk menjadi salah satu pengurus Partai Nasional Indonesia (PNI) yang didirikan oleh Presiden Soekarno dalam merebut dan memperjuangkan kemerdekaan. Kemudian setelah terbentuknya Partai Masyumi, Syekh Jamal pun turut andil dalam kepengurusan tentu dengan alasan bahwa Partai Masyumi merupakan jembatan aspirasi umat Islam saat itu.

Sepanjang hidupnya, Syekh Jamal Usman Padaelo juga rajin membaca kitab-kitab kuning karya para ulama. Kitab-kitab yang beliau miliki sudah diwariskan pada menantunya yang juga merupakan murid kesayangannya yakni $\mathrm{KH}$. Abd. Muin Yusuf. Kitab-kitab itu pun sampai saat ini masih tersimpan rapi di Perpustakaan Pondok Pesantren Al Urwatul Wutsqaa Benteng 
Kecamatan Baranti Kabupaten Sidrap (Wawancara, Hj. Soraya Fandi Khalik, Putri $\mathrm{Hj}$. Aisyah binti Syekh Jamal Usman Padaelo, di Rappang 7 Agustus 2018).

Melihat sepak terjang Syekh Jamal Usman Padaelo sebagaimana yang telah diuraikan di atas, sangat tepat kiranya jika beliau disebut sebagai Mahaguru para ulama di tanah Bugis Khususnya di Kota Rappang.

Pada usia 82 tahun tepatnya pada tanggal 27 April 1958 Syekh Jamal Usman Padaelo tutup usia. Beliau dimakamkan di Pekuburan Baqi Kelurahan Lalebata Kota Rappang, sekitar 1 (satu) kilometer dari rumah kediamannya. Hal ini pun menjadi sebuah tanda bahwa Kota Rappang sejak dulu menjadi tempat bermukimnya para ulama.

\section{PENUTUP}

Wilayah Sidrap dan Parepare merupakan salah satu wilayah di Sulawesi Selatan dengan jaringan ulama yang terbangun secara intens. Mereka mengadakan rihlah ke Mekah sebagai pusat magnet pendalaman Islam. Sebelum ke Mekah, beberapa ulama ini terlebih dahulu menimba ilmu di Tanah Bugis. Transmisi keilmuan mereka terjalin dalam hubungan antara guru dan murid. Untuk lebih mengeratkan jaringan ulama ini mereka pun menjalin tali kekerabatan dengan jalan perkawinan. Tersebutlah para ulama di dua tempat ini antara lain KH. Bahsen Salman, KH. Mahmud Fasieh, KH. Muhammad Sanusi Maggu, Hakim Lukman dan Syekh Jamal Usman Padaelo.

\section{DAFTAR PUSTAKA}

Azra, Azyumardi. 2007. Jaringan Ulama Timur Tengah dan Kepulauan Nusantara Abad XVII \& XVIII. Jakarta. Kencana Prenada Media Group.

Abdurrahman, Emsoe. 2016. H Tempo Doeloe, Kisah Klasik Berangkat $H$ Zaman Dahulu Bandung: MCM Publishing.

Burhanuddin, Jajat. 2012. Ulama dan Kekuasaan. (Pergumulan Elite Muslim Dalam Sejarah Indonesia) Indonesia: Mizan Publika.

Bruinessen, Van Martin. 2015. Kitab Kuning, Pesantren dan Tarekat. Yogyakarta: Penerbit Gading Publishing.

Dhofier, Zamakhsyari. 2011. Tradisi Pesantren (Studi Pandangan Hidup Kyai dan Visinya Mengenai Masa Depan Indonesia): Jakarta LP3ES.

Glasse, Cyril. 2015 Ensiklopedi Islam. Cet. III. Jakarta: Raja Grafindo Persada.

Hamid, Wardiah. 2017. Peran Orang Arab dalam Pendidikan Keagamaan di Kabupaten Maros, dalam Jurnal Pusaka, Volume 5 Nomor 2 Tahun 2017 (hal 257-268)

Kersten, Carool. 2017. Mengislamkan Indonesia (Sejarah Peradaban Islam di Indonesia). Tangerang Selatan : Penerbit Baca.

Bosra, Mustari.et.al. 2015. Menapak Jejak Menata Langkah: Sejarah Gerakan dan Biografi KetuaKetua Muhammadiyah Sulawesi Selatan. Yogyakarta: Suara Muhammadiyah.

Milles, M.B. and Huberman, M.A. 1984. Qualitative Data Analiysis. London: Sage Publication. 